Reka Buana : Jurnal Ilmiah Teknik Sipil dan Teknik Kimia, 4 (1), 2019, page 68-76

Tersedia online di https://jurnal.unitri.ac.id/index.php/rekabuana

ISSN 2503-2682 (Online)

ISSN 2503-3654 (Cetak)

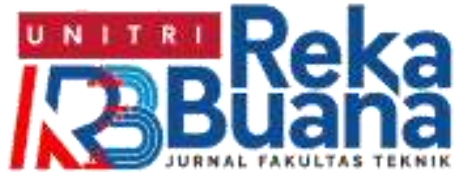

\title{
Analisis Potensi Likuifaksi dengan Metode Deterministik di Wilayah Surabaya
}

\author{
Himatul Farichah ${ }^{1}$ \\ ${ }^{1}$ Teknik Sipil, Fakultas Teknik, Universitas Muhammadyah Surabaya, J1 Raya Sutorejo No 59, Dukuh Sutorejo, \\ Mulyorejo, Surabaya, 60113 Indonesia \\ Email : cichafarichah@gmail.com
}

\begin{abstract}
ABSTRAK
Kota Surabaya dilewati oleh dua patahan aktif yang berpotensi gempa berkekuatan $6.5 \mathrm{M}_{\mathrm{w}}$. Selain itu, Wilayah kota Surabaya merupakan daerah yang rata-rata dataran rendah, yang berkisar 80\% merupakan endapan alluvial. Sehingga perlu dilakukan analisis potensi likuifaksi. Analisis potensi likuifaksi hanya dilakukan pada data tanah wilayah Surabaya Pusat. Analisis awal potensi likuifaksi dilakukan berdasarkan aspek gradasi tanah, relative density (DR), fine content (FC), derajat kejenuhan (SR), dan jumlah pukulan SPT. Sedangkan analisis lanjutan dengan menghitung Cyclic Shear Ratio (CSR), Cyclic Resistance Ratio (CRR), dan Factor of safety (FS) dengan menggunakan metode Youd dan Idriss 2001 dan metode Idriss 2008. Analisis awal kemudian dibandingkan dengan analisis lanjutan untuk disimpulkan potensi likuifaksinya. Berdasarkan analisis awal, pada kedalaman 1-7 m masih ada potensi likuifaksi, sedangkan tidak ada lagi potensi likuifaksi pada kedalaman lebih dari $22 \mathrm{~m}$. Berdasarkan analisis lanjutan dan kesimpulan analisis, hampir semua kedalaman memiliki potensi likuifaksi hingga kedalaman $17 \mathrm{~m}$.
\end{abstract}

Kata kunci : Likuifaksi, gempa, analisis potensi likuifaksi

\begin{abstract}
Surabaya is traveled by two active faults which can trigger earthquake of magnitude $6.5 \mathrm{Mw}$. Moreover, on average, Surabaya area is a lowland which is dominated with alluvial deposits. Thus, liquefaction potential analysis is required. The soil data used in this analysis was taken from the center of Surabaya. The initial analysis of liquefaction potential was conducted by considering the soil gradation, the relative density (DR), the fine content (FC), the degree of saturation (SR) and the SPT number. However, the advanced analysis was undertaken by utilizing Youd and Idriss 2001 and Idriss 2008 method. Thereafter, the conclusion of the potential analysis was obtained by comparing the results of initial analysis and advanced analysis. The results of initial analysis show that, generally, the soil has potential to be liquefied at the depth 1-7m, however at the depth $22 \mathrm{~m}$ the soil is not liquefied. Moreover, the results of advanced analysis and the conclusions of the analysis show that the soil has a liquefied potential at the depth $17 \mathrm{~m}$ from the surface.
\end{abstract}

Keywords : liquefaction; earthquake; analysis of liquefaction potential

Cara Mengutip : Farichah, H. (2019). Analisis Potensi Likuifaksi dengan Metode Deterministik di Wilayah Surabaya. Reka Buana: Jurnal Imiah Teknik Sipil dan Teknik Kimia, 4 (1), 68-76.

http://dx.doi.org/10.33366/rekabuana.v4i1.1195 


\section{PENDAHULUAN}

Likuifaksi adalah sebuah fenomena ketika tanah kehilangan kekuatan dan kekakuannya akibat goyangan yang dihasilkan dari bencana gempa bumi. Likuifaksi hanya terjadi pada jenis tanah pasir lepas yang jenuh atau tersaturasi [1]. Likuifaksi tergantung dari getaran yang terjadi, partikel tanah, kepadatan, dan muka air tanah. Pada umumnya likufaksi terjadi dipicu oleh Gempa yang besar [2]. Gempa bumi besar di dunia seperti di Taiwan (1999), Turkey (1999), Northridge (1994), Niigata \& Alaska (1964), dan India (1993 dan 1999) tersebut mengakibatkan terjadinya likuifaksi. Berdasarkan kejadian di dunia tersebut, gempa dengan kekuatan 6.0 $\mathrm{M}_{\mathrm{w}}$ dapat memicu terjadinya likuifaksi. Seperti dua gempa di India yaitu gempa Latur (1993) dengan kekuatan $6.2 \mathrm{M}_{\mathrm{w}}$ dan gempa Jabalpur (1997) dengan $6.0 \mathrm{M}_{\mathrm{w}}$.

Kota Surabaya menurut penemuan Pusat Studi Gempa Nasional pada tahun 2016 adalah kota yang terdapat dua patahan bumi yang diperkirakan masih aktif. Kedua patahan tersebut adalah sesar Kendeng dan sesar Waru yang membentang membelah Surabaya menjadi dua bagian yaitu utara dan selatan. Sesar Kendeng di Surabaya ini berpotensi menghasilkan gempa dengan goncagan kategori strong (kuat) hingga very strong (sangat kuat) [3]. Menurut Amien dalam [4] Kerusakan yang diakibatkan oleh gempa tersebut bisa mengakibatkan kerusakan yang sangat besar, karena gempa yang terjadi bisa mencapai $6.5 \mathrm{M}_{\mathrm{w}}$. Selain itu, Wilayah kota Surabaya merupakan daerah yang rata-rata dataran rendah, yang berkisar 80\% merupakan endapan alluvial dan sisanya merupakan perbukitan rendah yang dibentuk oleh tanah hasil dari pelapukan batuan tersier [5]. Secara geologi,
Surabaya juga berupa cekungan endapan aluvial muda hasil endapan laut dan sungai, tuf dan batu pasir [6]. Sehingga perlu adanya dilakukan analisis terhadap potensi likuifaksi pada wilayah Surabaya.

Secara umum studi terdahulu mengidentifikasi likuifaksi berdasarkan beberapa aspek, yaitu:

- Aspek Gradasi, mengelompokkan hail analisa ayakan suatu lapisan tanah, dimana zone A atau Zona B [7] termasuk dalam kategori berpotensi likuifaksi seperti pada Gambar 1.

- Aspek relative density (DR), berapa nilai DR yang dibutuhkan agar tidak terjadi likuifaksi [1]

- Aspek Fine content (FC) dan PI (Plastisity Index), tanah cohesionless yang memiliki kurang dari 15 persen (berat) partikel lebih kecil dari $0,005 \mathrm{~mm}$, liquid limit (Batas cair) kurang dari 35 persen, dan kandungan air in situ lebih besar dari 0,9 kali batas cair dapat rentan terhadap likuifaksi [8].

- Aspek Derajat Kejenuhan (SR) dan Kedalaman, Meskipun tanah yang memiliki water content rendah telah dilaporkan mengalami likuifaksi, setidaknya 80 hingga 85 persen derajat kejenuhan umumnya dianggap sebagai kondisi yang diperlukan tanah untuk mengalami likuifaksi. Lapisan yang berada 15 meter dari permukaan tanah lebih mungkin terjadi likuifaksi daripada lapisan yang lebih dalam [8]

- Aspek jumlah pukulan SPT, Lapisan tanah dengan Jumlah Pukulan SPT yang dinormalkan $(\mathrm{N} 1)_{60}<22$ memiliki kemungkinan untuk terjadi likuifaksi. Mercuson 1990 menyarankan jumlah SPT $(\mathrm{N} 1)_{60}<30$ sebagai ambang untuk mencurigai potensi likuifaksi [9]. Nilai 
$(\mathrm{N} 1)_{60}$ pada analisa ini diitung menggunakan persamaan metode YoudIdriss [10].

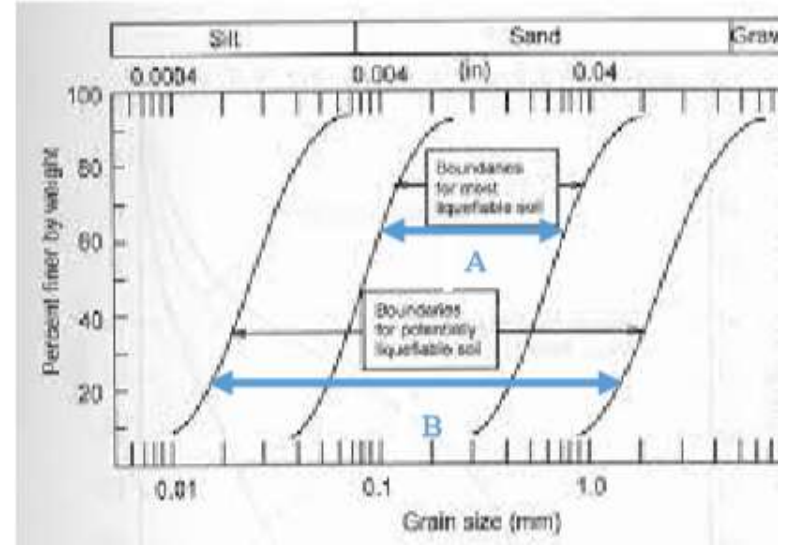

\section{Gambar 1. Batas-batas tanah yang berpotensi likuifaksi [7]}

- Cyclic Stress Ratio (CSR), Cyclic Resistance Ratio (CRR) dan Factor of safety (FS), dihitung berdasarkan data Standard
Penetration Test (SPT) dengan menggunakan dua metode. Metode YoudIdriss [10] dalam [11] yaitu dengan analisis potensi likuifaksi. CSR, rd (faktor reduksi kedalaman) ditentukan berdasarkan rentang kedalaman. Nilai CRR ditentukan dari besarnya nilai SPT yang dikoreksi berdasarkan nilai FC $\left((\mathrm{N} 1)_{60 \mathrm{cs}}\right)$. Alur analisis menggunakan metode ini disajikan pada Gambar 2. Metode yang kedua yaitu Idriss and Boulanger [12] dalam [11] mengusulkan metode analisis semi empiris likuifaksi akibat gempa. Metode ini menggunakan FC dan SPT terkoreksi ((N1)60cs) dalam perhitungan CRR. Metode ini juga menggunakan koreksi tekanan overburden (Ks). Bagan alir metode ini disajikan pada Gambar 3.

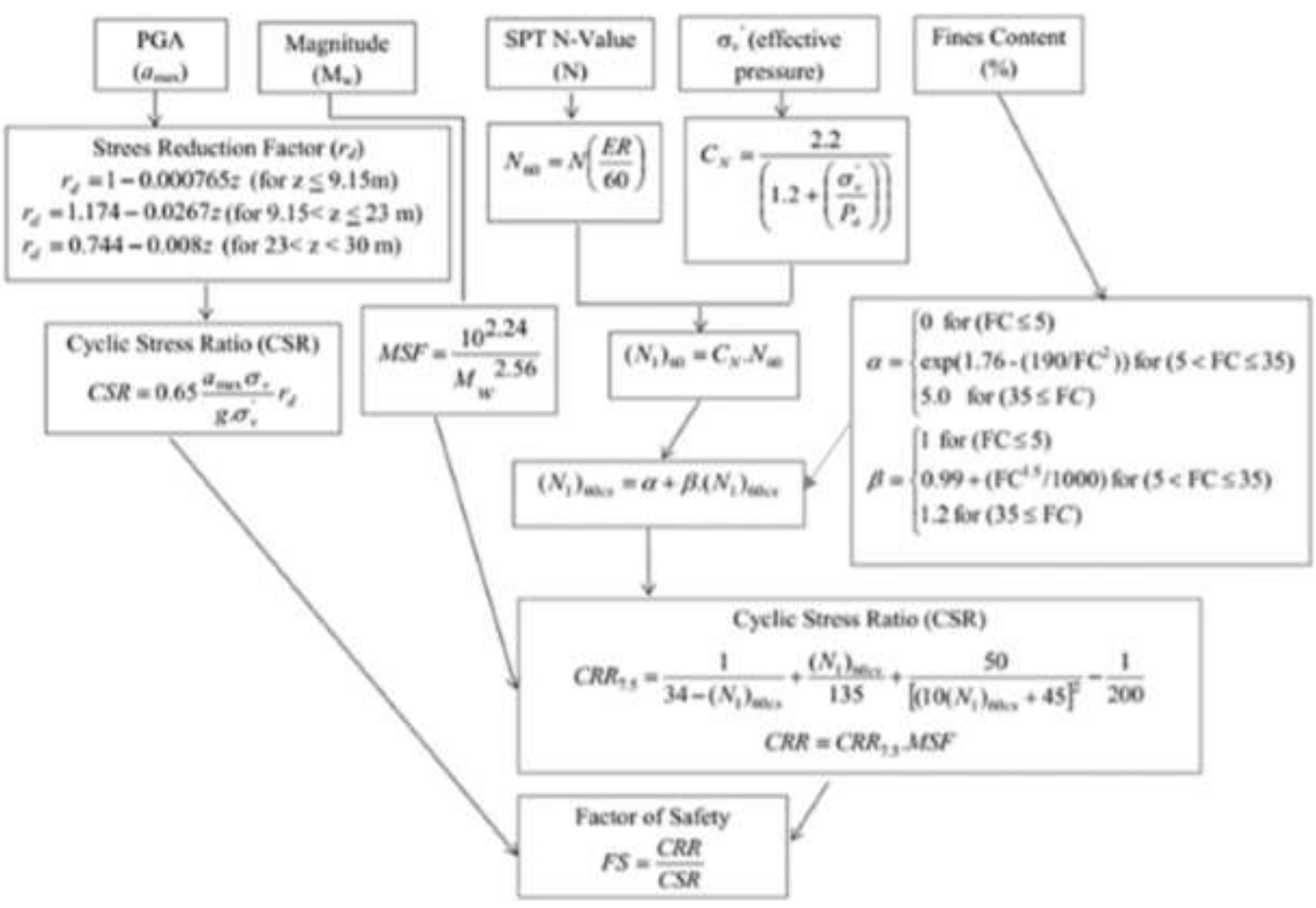

Gambar 2. Bagan alir Metode Youd-Idriss [11] 


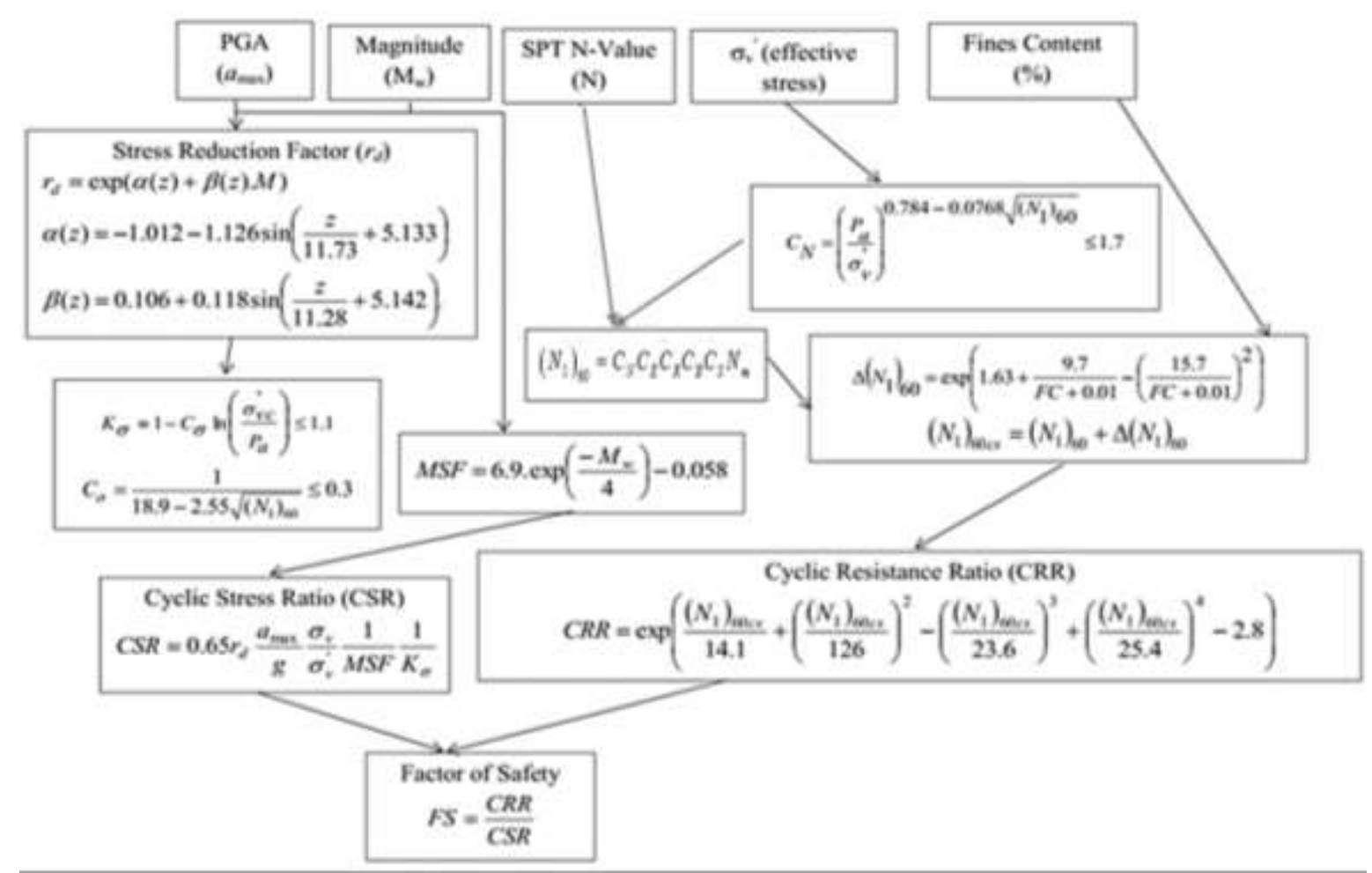

Gambar 3. Bagan alir Metode Idriss and Boulanger [11]

\section{METODE PENELITIAN}

\subsection{Data Gempa}

Data gempa yang digunakan dalam penelitian ini adalah mengacu pada SNI 8460-2017 Persyaratan Perancangan Geoteknik [13]. Untuk kegempaan bangunan gedung dan non gedun, kriteria perancangan gempa digunakan umur rencana 50 tahun, probabilitas terlampaui $2 \%$, dan periode ulang 2500 tahun. Sehingga didapatkan dari Peta Sumber dan Bahaya Gempa Indonesia Tahun 2017 bahwa Peak Ground Acceleration (PGA) wilayah Surabaya adalah 0.3-0.4 g. Dalam penelitian ini digunakan PGA $0.4 \mathrm{~g}$ dan kekuatan gempa $6.0 \mathrm{M}_{\mathrm{w}}$.

\subsection{Data Tanah}

Data tanah yang digunakan dalam pelatihan ini adalah data tanah yang diambil di lokasi Surabaya Pusat. Terdapat tiga sampel tanah dari tiga lokasi yang berbeda dengan nama $\mathrm{BH} 1, \mathrm{BH} 2$, dan $\mathrm{BH}-3$. Diantaranya data tanah yang digunakan adalah berupa SPT (Gambar 4), gamma tanah, kurva gradasi, nilai FC (Gambar 4), SR, dan DR.

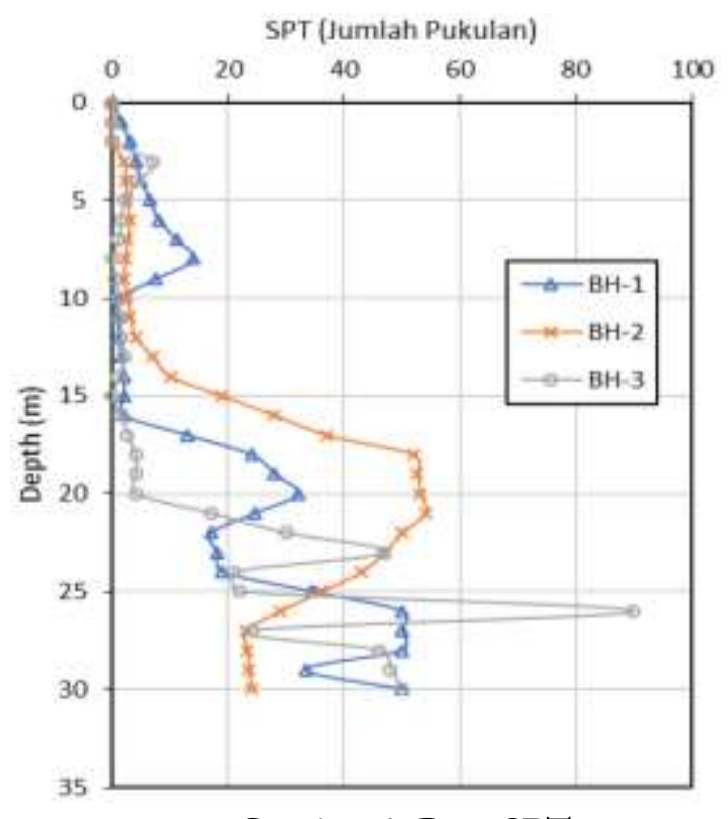

Gambar 4. Data SPT 


\subsection{Analisis Awal Potensi Likuifaksi}

Analisis awal potensi likuifaksi ini melihat potensi likuifaksi berdasarkan lima aspek, yaitu aspek gradasi, DR, FC (yang masing-masing data tanah di tunjukkan di Gambar 5), SR, dan jumlah pukulan (N1) 60 setiap kedalaman lapisan tanah. Dari kelima aspek tersebut pada setiap kedalaman kemudian dibandingkan jika lebih dari 50\% menyatakan likuifaksi, maka hasil analisa awal pada keladaman tersebut dianggap berpotensi likuifaksi.

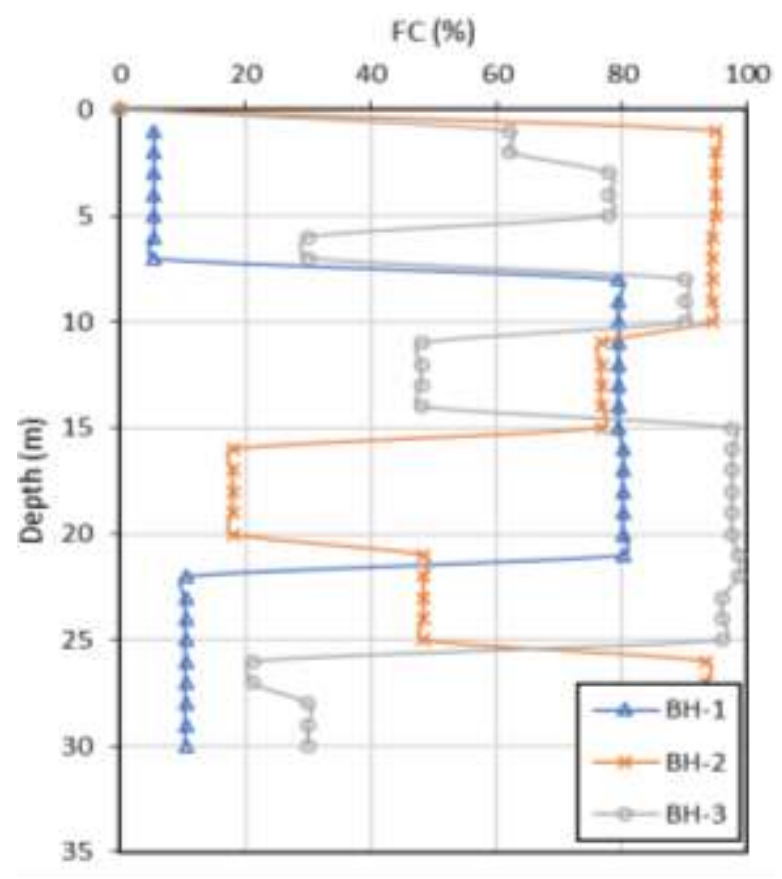

Gambar 5. Rekapitulasi nilai FC

\subsection{Analisis Lanjutan Potensi Likuifaksi}

Analisis lanjutan dengan memasukkan input dan menghitung sesuai dengan bagan alir. CSR, CRR, dan SF setiap kedalaman dihitung menggunakan dua metode. Masing-masing metode memberikan nilai CSR, CRR dan SF yang berbeda. Jika SF menunjukkan angka dibawah 1.5, itu artinya pada kedalaman tersebut tanah berpotensi likuifaksi. Hasil dari kedua metode tersebut dibandingkan, Jika salah satunya menyatakan likuifaksi, maka dari hasil analisis lanjutan menganggap bahwa pada kedalaman tersebut berpotensi terjadi likuifaksi.

\subsection{Kesimpulan analisis Potensi Likuifaksi}

Setelah mendapatkan potensi likuifaksi setiap kedalaman tanah pada analisis awal dan analisis lanjutan, untuk mendapatkan kesimpulan apakah pada lapisan tersebut berpotensi terjadi likuifaksi, hasil analisis awal dibandingkan dengan analisis lanjutan. Jika salah satunya menyatakan likuifaksi, maka dapat disimpulkan bahwa pada kedalaman tersebut berpotensi terjadi likuifaksi.

\section{HASIL DAN PEMBAHASAN}

\subsection{Hasil analisis Awal}

Hasil Analisis awal pada Tabel 1 merupakan hasil menggunakan data tanah BH-1.

Tabel 1. Analisis Awal data tanah BH-1

\begin{tabular}{ccccccc}
\hline $\begin{array}{c}\text { Depth } \\
(\mathrm{m})\end{array}$ & Gradasi & DR & FC & SR & SPT & $\begin{array}{c}\text { Kesimpulan } \\
\text { Analisis } \\
\text { Awal }\end{array}$ \\
\hline 1 & L & L & L & L & L & L \\
\hline 2 & L & L & L & L & L & L \\
\hline 3 & L & L & L & L & L & L \\
\hline 4 & L & L & L & L & L & L \\
\hline 5 & L & L & L & L & L & L \\
\hline 6 & L & L & L & L & L & L \\
\hline 7 & L & L & L & L & L & L \\
\hline 8 & $\mathbf{A}$ & $\mathbf{A}$ & $\mathbf{A}$ & L & L & $\mathbf{A}$ \\
\hline 9 & $\mathbf{A}$ & $\mathbf{A}$ & $\mathbf{A}$ & $\mathrm{L}$ & $\mathrm{L}$ & $\mathbf{A}$ \\
\hline 10 & $\mathbf{A}$ & $\mathbf{A}$ & $\mathbf{A}$ & $\mathrm{L}$ & $\mathrm{L}$ & $\mathbf{A}$ \\
\hline 11 & $\mathbf{A}$ & $\mathbf{A}$ & $\mathbf{A}$ & $\mathrm{L}$ & $\mathrm{L}$ & $\mathbf{A}$ \\
\hline 12 & $\mathbf{A}$ & $\mathbf{A}$ & $\mathbf{A}$ & $\mathrm{L}$ & $\mathrm{L}$ & $\mathbf{A}$ \\
\hline 13 & $\mathbf{A}$ & $\mathbf{A}$ & $\mathbf{A}$ & $\mathrm{L}$ & $\mathrm{L}$ & $\mathbf{A}$ \\
\hline 14 & $\mathbf{A}$ & $\mathbf{A}$ & $\mathbf{A}$ & $\mathrm{L}$ & $\mathrm{L}$ & $\mathbf{A}$ \\
\hline 15 & $\mathbf{A}$ & $\mathbf{A}$ & $\mathbf{A}$ & $\mathrm{L}$ & $\mathrm{L}$ & $\mathbf{A}$ \\
\hline 16 & $\mathbf{A}$ & $\mathbf{A}$ & $\mathbf{A}$ & $\mathrm{L}$ & $\mathrm{L}$ & $\mathbf{A}$ \\
\hline 17 & $\mathbf{A}$ & $\mathbf{A}$ & $\mathbf{A}$ & $\mathrm{L}$ & $\mathrm{L}$ & $\mathbf{A}$ \\
\hline
\end{tabular}




\begin{tabular}{|c|c|c|c|c|c|c|}
\hline 18 & $\mathbf{A}$ & $\mathbf{A}$ & $\mathbf{A}$ & $\mathrm{L}$ & $\mathrm{L}$ & $\mathbf{A}$ \\
\hline 19 & $\mathbf{A}$ & $\mathbf{A}$ & $\mathbf{A}$ & $\mathrm{L}$ & $\mathrm{L}$ & $\mathbf{A}$ \\
\hline 20 & $\mathbf{A}$ & $\mathbf{A}$ & $\mathbf{A}$ & $\mathrm{L}$ & $\mathrm{L}$ & $\mathbf{A}$ \\
\hline 21 & $\mathbf{A}$ & $\mathbf{A}$ & $\mathbf{A}$ & $\mathrm{L}$ & $\mathrm{L}$ & $\mathbf{A}$ \\
\hline 22 & $\mathrm{~L}$ & $\mathrm{~L}$ & $\mathrm{~L}$ & $\mathrm{~L}$ & $\mathrm{~L}$ & $\mathrm{~L}$ \\
\hline 23 & $\mathrm{~L}$ & $\mathrm{~L}$ & $\mathrm{~L}$ & $\mathrm{~L}$ & $\mathrm{~L}$ & $\mathrm{~L}$ \\
\hline 24 & $\mathrm{~L}$ & $\mathrm{~L}$ & $\mathrm{~L}$ & $\mathrm{~L}$ & $\mathrm{~L}$ & $\mathrm{~L}$ \\
\hline 25 & $\mathrm{~L}$ & $\mathrm{~L}$ & $\mathrm{~L}$ & $\mathrm{~L}$ & $\mathrm{~L}$ & $\mathrm{~L}$ \\
\hline 26 & $\mathrm{~L}$ & $\mathrm{~L}$ & $\mathrm{~L}$ & $\mathrm{~L}$ & $\mathrm{~L}$ & $\mathrm{~L}$ \\
\hline 27 & $\mathrm{~L}$ & $\mathrm{~L}$ & $\mathrm{~L}$ & $\mathrm{~L}$ & $\mathrm{~L}$ & $\mathrm{~L}$ \\
\hline 28 & $\mathrm{~L}$ & $\mathrm{~L}$ & $\mathrm{~L}$ & $\mathrm{~L}$ & $\mathrm{~L}$ & $\mathrm{~L}$ \\
\hline 29 & $\mathrm{~L}$ & $\mathrm{~L}$ & $\mathrm{~L}$ & $\mathrm{~L}$ & $\mathbf{A}$ & $\mathrm{L}$ \\
\hline 30 & $\mathrm{~L}$ & $\mathrm{~L}$ & $\mathrm{~L}$ & $\mathrm{~L}$ & $\mathbf{A}$ & $\mathrm{L}$ \\
\hline
\end{tabular}

Dari Tabel 1 dapat dilihat bahwa data tanah BH-1 memiliki potensi likuifaksi pada dari kedalaman $1-7 \mathrm{~m}$. Sedangkan pada kedalaman 8-21 m menunjukkan aman terhadap likuifaksi. Tetapi dari kedalaman 22-30m menunjukkan potensi terjadi likuifaksi.

Tabel 2. Rekapitulasi analisis awal

\begin{tabular}{cccc}
\hline \multirow{2}{*}{$\begin{array}{c}\text { Depth } \\
(\mathrm{m})\end{array}$} & \multicolumn{3}{c}{ Kesimpulan Analisa Awal } \\
\cline { 2 - 4 } & BH-1 & BH-2 & BH-3 \\
\hline 1 & Likuifaksi & Aman & Aman \\
\hline 2 & Likuifaksi & Aman & Aman \\
\hline 3 & Likuifaksi & Aman & Aman \\
\hline 4 & Likuifaksi & Aman & Aman \\
\hline 5 & Likuifaksi & Aman & Likuifaksi \\
\hline 6 & Likuifaksi & Aman & Likuifaksi \\
\hline 7 & Likuifaksi & Aman & Likuifaksi \\
\hline 8 & Aman & Aman & Aman \\
\hline 9 & Aman & Aman & Aman \\
\hline 10 & Aman & Aman & Aman \\
\hline 11 & Aman & Aman & Aman \\
\hline 12 & Aman & Aman & Aman \\
\hline 13 & Aman & Aman & Aman \\
\hline 14 & Aman & Aman & Aman \\
\hline 15 & Aman & Aman & Aman \\
\hline 16 & Aman & Likuifaksi & Aman \\
\hline
\end{tabular}

\begin{tabular}{cccc}
\hline 17 & Aman & Likuifaksi & Aman \\
\hline 18 & Aman & Aman & Aman \\
\hline 19 & Aman & Aman & Aman \\
\hline 20 & Aman & Aman & Aman \\
\hline 21 & Aman & Aman & Aman \\
\hline 22 & Likuifaksi & Likuifaksi & Likuifaksi \\
\hline 23 & Likuifaksi & Likuifaksi & Likuifaksi \\
\hline 24 & Likuifaksi & Likuifaksi & Likuifaksi \\
\hline 25 & Likuifaksi & Likuifaksi & Likuifaksi \\
\hline 26 & Likuifaksi & Likuifaksi & Aman \\
\hline 27 & Likuifaksi & Likuifaksi & Likuifaksi \\
\hline 28 & Likuifaksi & Likuifaksi & Likuifaksi \\
\hline 29 & Likuifaksi & Likuifaksi & Likuifaksi \\
\hline 30 & Likuifaksi & Likuifaksi & Likuifaksi \\
\hline & & &
\end{tabular}

Keseluruhan analisis awal pada $\mathrm{BH}-1$, BH-2, dan BH-3 dapat dilihat pada Tabel 2. Dari Tabel 2 dapat dilihat bahwa dari kedalaman 1 - 15 dan 18-21 m data tanah BH-2 menunjukkan tidak ada potensi terjadi likuifaksi. Potensi likuifaksi ada pada kedalaman 16-17 $\mathrm{m}$ dan 22-30 $\mathrm{m}$. Pada data tanah BH-3, potensi likuifaksi ada pada kedalaman 5-7 $\mathrm{m}$ dan 22-30 $\mathrm{m}$. Sedangkan pada kedalaman 1-4 $\mathrm{m}$ dan 8-21 $\mathrm{m}$ menunjukkan aman terhadap likuifaksi. Secara garis besar dapat disimpulkan bahwa pada kedalaman 1-7 $\mathrm{m}$ masih ada potensi likuifaksi, sedangkan rata-rata aman terhadap likuifaksi pada kedalaman $8 \mathrm{~m}$.

\subsection{Hasil analisis Lanjutan}

SF dari setiap lapisan tanah dihitung menggunakan dua metode didapatkan sebagaimana pada Tabel 3. Dari Tabel 3 dapat dilihat bahwa dari kedalaman 1-7 m, 9-17m dan 22-24 m untuk data tanah BH-1 menunjukkan potensi terjadi likuifaksi. Nilai SF setiap kedalaman untuk data tanah $\mathrm{BH}$ 1, BH-2, dan BH-3 dilihat pada Gambar 6. 


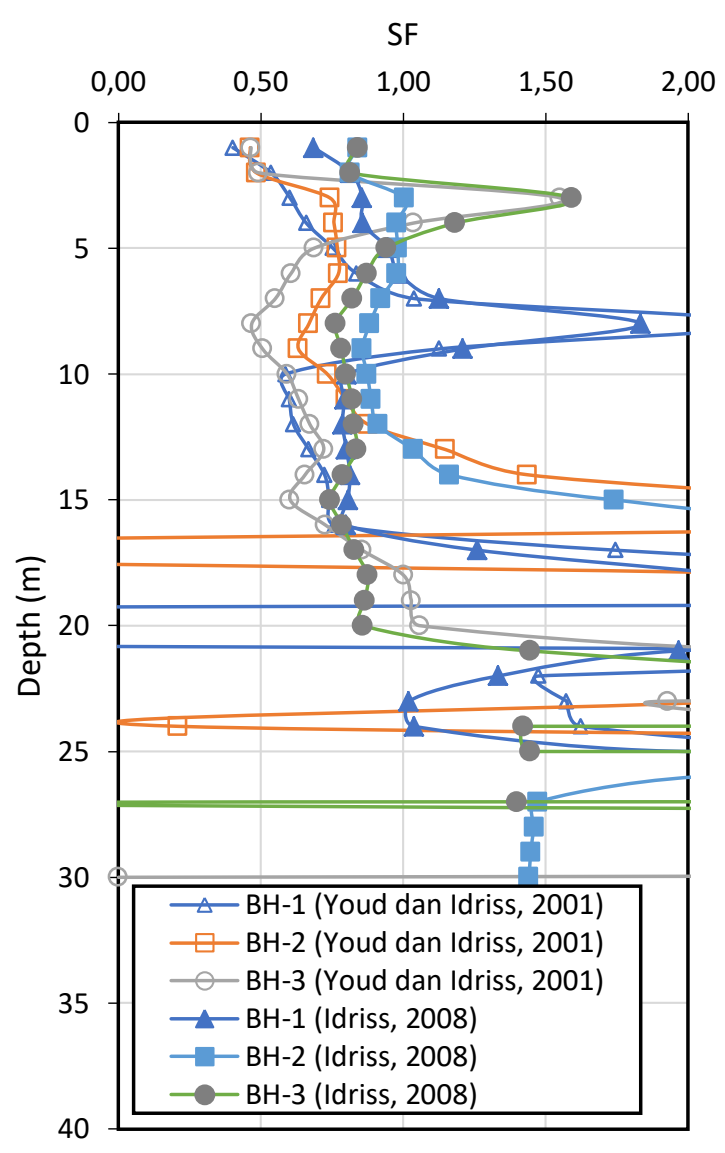

Gambar 6 Nilai SF di setiap kedalaman

Tabel 3. Analisis lanjutan data tanah BH-1

\begin{tabular}{|c|c|c|c|}
\hline & \multicolumn{2}{|c|}{ Analisis Lanjutan } & \multirow{2}{*}{$\begin{array}{c}\text { Kesimpulan } \\
\text { Analisa } \\
\text { Lanjutan }\end{array}$} \\
\hline Depth (m) & $\begin{array}{c}\text { Youd } \\
\text { dan } \\
\text { Idriss, } \\
2001\end{array}$ & $\begin{array}{l}\text { Idriss dan } \\
\text { Boulanger, } \\
2004\end{array}$ & \\
\hline 1 & $\mathrm{~L}$ & $\mathrm{~L}$ & $\mathrm{~L}$ \\
\hline 2 & $\mathrm{~L}$ & $\mathrm{~L}$ & $\mathrm{~L}$ \\
\hline 3 & $\mathrm{~L}$ & $\mathrm{~L}$ & $\mathrm{~L}$ \\
\hline 4 & $\mathrm{~L}$ & $\mathrm{~L}$ & $\mathrm{~L}$ \\
\hline 5 & $\mathrm{~L}$ & $\mathrm{~L}$ & $\mathrm{~L}$ \\
\hline 6 & $\mathrm{~L}$ & $\mathrm{~L}$ & $\mathrm{~L}$ \\
\hline 7 & $\mathrm{~L}$ & $\mathrm{~L}$ & $\mathrm{~L}$ \\
\hline 8 & A & A & $\mathbf{A}$ \\
\hline 9 & $\mathrm{~L}$ & $\mathrm{~L}$ & $\mathrm{~L}$ \\
\hline 10 & $\mathrm{~L}$ & $\mathrm{~L}$ & $\mathrm{~L}$ \\
\hline 11 & $\mathrm{~L}$ & $\mathrm{~L}$ & $\mathrm{~L}$ \\
\hline 12 & $\mathrm{~L}$ & $\mathrm{~L}$ & $\mathrm{~L}$ \\
\hline
\end{tabular}

\begin{tabular}{|c|c|c|c|}
\hline 13 & $\mathrm{~L}$ & $\mathrm{~L}$ & $\mathrm{~L}$ \\
\hline 14 & $\mathrm{~L}$ & $\mathrm{~L}$ & $\mathrm{~L}$ \\
\hline 15 & $\mathrm{~L}$ & $\mathrm{~L}$ & $\mathrm{~L}$ \\
\hline 16 & $\mathrm{~L}$ & $\mathrm{~L}$ & $\mathrm{~L}$ \\
\hline 17 & A & $\mathrm{L}$ & $\mathrm{L}$ \\
\hline 18 & $\mathbf{A}$ & $\mathbf{A}$ & $\mathbf{A}$ \\
\hline 19 & $\mathbf{A}$ & $\mathbf{A}$ & $\mathbf{A}$ \\
\hline 20 & $\mathrm{~L}$ & $\mathbf{A}$ & $\mathrm{L}$ \\
\hline 21 & A & $\mathbf{A}$ & $\mathbf{A}$ \\
\hline 22 & $\mathrm{~L}$ & $\mathrm{~L}$ & $\mathrm{~L}$ \\
\hline 23 & $\mathbf{A}$ & $\mathrm{L}$ & $\mathrm{L}$ \\
\hline 24 & $\mathbf{A}$ & $\mathrm{L}$ & $\mathrm{L}$ \\
\hline 25 & A & $\mathbf{A}$ & A \\
\hline 26 & A & $\mathbf{A}$ & $\mathbf{A}$ \\
\hline 27 & $\mathbf{A}$ & $\mathbf{A}$ & $\mathbf{A}$ \\
\hline 28 & $\mathbf{A}$ & $\mathbf{A}$ & A \\
\hline 29 & $\mathbf{A}$ & $\mathbf{A}$ & $\mathbf{A}$ \\
\hline 30 & $\mathbf{A}$ & $\mathbf{A}$ & $\mathbf{A}$ \\
\hline
\end{tabular}

Catatan: $\mathrm{L}=$ berpotensi likuifaksi, $\mathbf{A}=$ Aman

Rekapitulasi hasil kesimpulan Analisis lanjutan dengan menggunakan data $\mathrm{BH}-1$, BH-2, dan BH-3 dapat dilihat di Tabel 4. Dari Tabel 4, hampir semua kedalaman memiliki potensi likuifaksi hingga kedalaman $17 \mathrm{~m}$.

\section{Tabel 4. Rekapitulasi analisis lanjutan}

\begin{tabular}{cccc}
\hline \multirow{2}{*}{$\begin{array}{c}\text { Depth } \\
(\mathrm{m})\end{array}$} & \multicolumn{2}{c}{ Kesimpulan Analisis Lanjutan } \\
\cline { 2 - 4 } & BH-1 & BH-2 & BH-3 \\
\hline 1 & Likuifaksi & Likuifaksi & Likuifaksi \\
\hline 2 & Likuifaksi & Likuifaksi & Likuifaksi \\
\hline 3 & Likuifaksi & Likuifaksi & Aman \\
\hline 4 & Likuifaksi & Likuifaksi & Likuifaksi \\
\hline 5 & Likuifaksi & Likuifaksi & Likuifaksi \\
\hline 6 & Likuifaksi & Likuifaksi & Likuifaksi \\
\hline 7 & Likuifaksi & Likuifaksi & Likuifaksi \\
\hline 8 & Aman & Likuifaksi & Likuifaksi \\
\hline 9 & Likuifaksi & Likuifaksi & Likuifaksi \\
\hline 10 & Likuifaksi & Likuifaksi & Likuifaksi \\
\hline 11 & Likuifaksi & Likuifaksi & Likuifaksi \\
\hline 12 & Likuifaksi & Likuifaksi & Likuifaksi \\
\hline
\end{tabular}




\begin{tabular}{cccc}
\hline 13 & Likuifaksi & Likuifaksi & Likuifaksi \\
\hline 14 & Likuifaksi & Likuifaksi & Likuifaksi \\
\hline 15 & Likuifaksi & Aman & Likuifaksi \\
\hline 16 & Likuifaksi & Aman & Likuifaksi \\
\hline 17 & Likuifaksi & Likuifaksi & Likuifaksi \\
\hline 18 & Aman & Aman & Likuifaksi \\
\hline 19 & Aman & Aman & Likuifaksi \\
\hline 20 & Likuifaksi & Aman & Likuifaksi \\
\hline 21 & Aman & Aman & Likuifaksi \\
\hline 22 & Likuifaksi & Aman & Aman \\
\hline 23 & Likuifaksi & Aman & Aman \\
\hline 24 & Likuifaksi & Likuifaksi & Likuifaksi \\
\hline 25 & Aman & Aman & Likuifaksi \\
\hline 26 & Aman & Aman & Aman \\
\hline 27 & Aman & Likuifaksi & Likuifaksi \\
\hline 28 & Aman & Likuifaksi & Aman \\
\hline 29 & Aman & Likuifaksi & Aman \\
\hline 30 & Aman & Likuifaksi & Aman \\
\hline & & &
\end{tabular}

\begin{tabular}{cccc}
\hline 12 & Likuifaksi & Likuifaksi & Likuifaksi \\
\hline 13 & Likuifaksi & Likuifaksi & Likuifaksi \\
\hline 14 & Likuifaksi & Likuifaksi & Likuifaksi \\
\hline 15 & Likuifaksi & Aman & Likuifaksi \\
\hline 16 & Likuifaksi & Likuifaksi & Likuifaksi \\
\hline 17 & Likuifaksi & Likuifaksi & Likuifaksi \\
\hline 18 & Aman & Aman & Likuifaksi \\
\hline 19 & Aman & Aman & Likuifaksi \\
\hline 20 & Likuifaksi & Aman & Likuifaksi \\
\hline 21 & Aman & Aman & Likuifaksi \\
\hline 22 & Likuifaksi & Likuifaksi & Aman \\
\hline 23 & Likuifaksi & Likuifaksi & Aman \\
\hline 24 & Likuifaksi & Likuifaksi & Likuifaksi \\
\hline 25 & Aman & Likuifaksi & Likuifaksi \\
\hline 26 & Aman & Likuifaksi & Aman \\
\hline 27 & Aman & Likuifaksi & Likuifaksi \\
\hline 28 & Aman & Likuifaksi & Aman \\
\hline 29 & Aman & Likuifaksi & Aman \\
\hline 30 & Aman & Likuifaksi & Aman \\
\hline & & &
\end{tabular}

Sedangkan Tabel 5 menunjukkan hasil kesimpulan analisis, yaitu setelah membandingkan hasil kesimpulan analisis awal (Tabel 2) dan hasil kesimpulan analisis lanjutan (Tabel 4). Dapat disimpulkan bahwa pasa Tabel 5, secara umum likuifaksi terjadi hingga kedalaman $17 \mathrm{~m}$.

Tabel 5. Rekapitulasi analisis likuifaksi

\begin{tabular}{cccc}
\hline \multirow{2}{*}{$\begin{array}{c}\text { Depth } \\
(\mathrm{m})\end{array}$} & \multicolumn{3}{c}{ Kesimpulan Analisis } \\
\cline { 2 - 4 } & BH-1 & BH-2 & BH-3 \\
\hline 1 & Likuifaksi & Likuifaksi & Likuifaksi \\
\hline 2 & Likuifaksi & Likuifaksi & Likuifaksi \\
\hline 3 & Likuifaksi & Likuifaksi & Aman \\
\hline 4 & Likuifaksi & Likuifaksi & Likuifaksi \\
\hline 5 & Likuifaksi & Likuifaksi & Likuifaksi \\
\hline 6 & Likuifaksi & Likuifaksi & Likuifaksi \\
\hline 7 & Likuifaksi & Likuifaksi & Likuifaksi \\
\hline 8 & Aman & Likuifaksi & Likuifaksi \\
\hline 9 & Likuifaksi & Likuifaksi & Likuifaksi \\
\hline 10 & Likuifaksi & Likuifaksi & Likuifaksi \\
\hline 11 & Likuifaksi & Likuifaksi & Likuifaksi
\end{tabular}

\section{KESIMPULAN}

Dari hasil pengolahan data dan analisa data yang telah dilakukan pada penelitian Akhir ini, dapat diambil kesimpulan bahwa:

1. Berdasarkan analisis awal, pada kedalaman 1-7 m masih ada potensi likuifaksi, sedangkan tidak ada lagi potensi likuifaksi pada kedalaman lebih dari $22 \mathrm{~m}$.

2. Berdasarkan analisis lanjutan, hampir semua kedalaman memiliki potensi likuifaksi hingga kedalaman $17 \mathrm{~m}$.

3. Berdasarkan kesimpulan analisis, secara umum likuifaksi terjadi hingga kedalaman $17 \mathrm{~m}$.

4. Diperlukan data tanah yang lebih banyak dan lebih lengkap untuk penelitian selanjutnya.

5. Diperlukan perbandingan dengan metode-metode yang lain dalam menganalisis potensi likuifaksi. 


\section{DAFTAR PUSTAKA}

[1] Seed, H. B. dan Idriss, I. M. (1971). Simplified Procedure for Evaluating Soil Liquefaction Potential. J. Geotech. Engrg., ASCE 97. 9:1249-1273.

[2] Tosun, H., Seyrek, E., Orhan, A., Savas, H., dan Turkoz, M., (2011), Soil Liquefaction Potential In Eskisehir, NW Turkey. Natural hazards and Earth System Sciences,11:1071-1082.

[3] Rachmaningtyas, A. P., Purwanto, M. S., Widodo, A. (2017). Identifikasi Percepatan Tanah Maksimum (PGA) dan Kerentanan Tanah Menggunakan Metode Mikritremor Jalur Sesar Kendeng. Jurnal Geosaintek 03, no 2, 107-114.

[4] Effendi, Zaenal "Surabaya Dilewati 2 Patahan Aktif, Berpotensi Gempa darat 6,5 SR", detik news, 08 November 2017.

[5] Bahri, S dan Madlazim, (2012) Pemetaan Topografi, Geofisika dan Geologi Kota Surabaya, Jurnal Penelitian Fisika dan Aplikasinya. ISSN: 20879946.

[6] Soekardi, Geologi Lembar Pacitan, Jawa, Pusat Penelitian dan Pengembangan Geologi Indonesia, 1992

[7] Tsuchida, H., (1970) Evaluation of liquefaction potential of sandy deposits and measures against liquefaction induced damaged. Proceedings of the annual seminar of the Port and Habour Research Institute, 3-1:3-33.

[8] Seed, H. B., dan Idriss, I. M. (1982). "Ground motions and sol liquefaction during earthquakes," Earthquake Engineering Reseaerch Institute Monograph, Oakland, Calif
[9] Mercuson III, W. F., Hynes, M.E., \& Franklin, A. G. (1990). Evaluation and se of residual strength in seismic safely analysis of embankments. Earthquake Spectra 6, 3:529-572.

[10] Youd T.L., dan Idriss, I.M (2001). Liquefaction Resistance of Soils: Summary Report from The1996 NCEER and 1998 NCEER/NSF Workshops on Evaluation of Liquefaction Resistance of Soils, Journal of Geotechnical and Geoenvironmental Engineering Div, ASCE 127. 4:297-313.

[11] Mase, Z. L., (2018). Studi kehandalan metode analisis likuifaksi menggunakan SPT Akibat Gempa 8,6 Mw, 12 September 2007 di Area Pesisir Kota Bengkulu, JurnalTeoretis dan Terapan Bidang Rekayasa Sipil, 25(1):53-60.

[12] Idriss, I.M., dan Boulanger, R.W., 2008, Soil Liquefaction During Earthquakes, Earthquake Engineering Research Institute (EERI), USA.

[13] SNI 8460-2017, 2017. Persyaratan Perancangan Geoteknik. Bandung: Badan Standarisasi Nasional 
